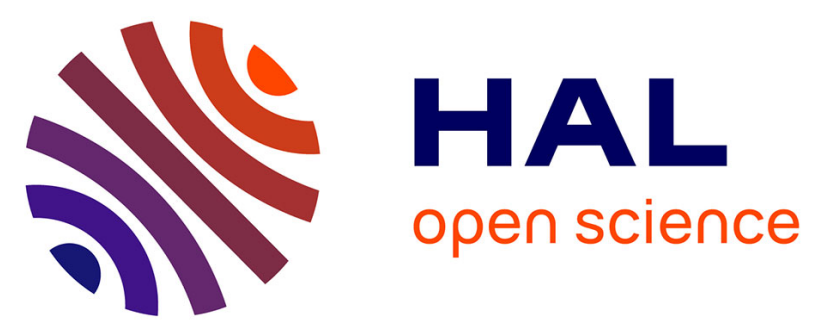

\title{
Expeditious synthesis of 1,1-diarylethylenes related to isocombretastatin A-4 (isoCA-4) via palladium-catalyzed arylation of $\mathrm{N}$-tosylhydrazones with aryl triflates
}

\author{
Jean-Daniel Brion, Mouad Alami, Bret Tréguier, Abdallah Hamze, Olivier
} Provot

\section{To cite this version:}

Jean-Daniel Brion, Mouad Alami, Bret Tréguier, Abdallah Hamze, Olivier Provot. Expeditious synthesis of 1,1-diarylethylenes related to isocombretastatin A-4 (isoCA-4) via palladium-catalyzed arylation of N-tosylhydrazones with aryl triflates. Tetrahedron Letters, 2009, 50 (47), pp.6549-6552. 10.1016/j.tetlet.2009.09.046 . hal-02394584

\section{HAL Id: hal-02394584 \\ https://hal.science/hal-02394584}

Submitted on 4 Dec 2019

HAL is a multi-disciplinary open access archive for the deposit and dissemination of scientific research documents, whether they are published or not. The documents may come from teaching and research institutions in France or abroad, or from public or private research centers.
L'archive ouverte pluridisciplinaire HAL, est destinée au dépôt et à la diffusion de documents scientifiques de niveau recherche, publiés ou non, émanant des établissements d'enseignement et de recherche français ou étrangers, des laboratoires publics ou privés. 


\section{Expeditious synthesis of 1,1-diarylethylenes related to isocombretastatin A-4 (isoCA-4) via palladium-catalyzed arylation of $\mathrm{N}$-tosylhydrazones with aryl triflates}

Bret Tréguier, Abdallah Hamze, Olivier Provot, Jean-Daniel Brion, Mouad Alami

\section{To cite this version:}

Bret Tréguier, Abdallah Hamze, Olivier Provot, Jean-Daniel Brion, Mouad Alami. Expeditious synthesis of 1,1-diarylethylenes related to isocombretastatin A-4 (isoCA-4) via palladium-catalyzed arylation of N-tosylhydrazones with aryl triflates. Tetrahedron Letters, Elsevier, 2009, 50 (47), pp.65496552. 10.1016/j.tetlet.2009.09.046 . hal-02394584

\section{HAL Id: hal-02394584 \\ https://hal.archives-ouvertes.fr/hal-02394584}

Submitted on 4 Dec 2019

HAL is a multi-disciplinary open access archive for the deposit and dissemination of scientific research documents, whether they are published or not. The documents may come from teaching and research institutions in France or abroad, or from public or private research centers.
L'archive ouverte pluridisciplinaire HAL, est destinée au dépôt et à la diffusion de documents scientifiques de niveau recherche, publiés ou non, émanant des établissements d'enseignement et de recherche français ou étrangers, des laboratoires publics ou privés. 


\title{
Expeditious Synthesis of 1,1-Diarylethylenes Related to Isocombretastatin A-4 (isoCA4) via Palladium-Catalyzed Arylation of $N$-Tosylhydrazones with Aryl Triflates
}

\author{
Bret Tréguier, Abdallah Hamze, Olivier Provot, Jean-Daniel Brion and Mouâd Alami* \\ Univ Paris-Sud, CNRS, BioCIS UMR 8076, Laboratoire de Chimie Thérapeutique, Faculté de Pharmacie, 5 rue J.-B. Clément, Châtenay- \\ Malabry, F-92296, France.
}

\begin{abstract}
A quick and efficient entry to 1,1-diarylethylenes via the reaction of poly-oxygenated aryl $N$-tosylhydrazones with aryl triflates is described. The reaction employs the catalytic system $\mathrm{Pd}(\mathrm{OAc})_{2} / \mathrm{XPhos}, t \mathrm{BuOLi}$ as the base and dioxane as the solvent. A variety of substituents on both coupling partner's hydrazones and triflates are tolerated. This procedure provides a complementary route to the existing methods for the access to 1,1-diarylethylenes of biological interest.
\end{abstract}

Combretastatins CA-4 and CA-1 are a very interesting class of cytotoxic agents of natural origin, which have received much attention due to their simple structures, their high potency as cytotoxic and antimitotic agents as well as their ability to selectively damage tumor neovasculature $^{1}$ Despite their remarkable anticancer activities, these $Z$-stilbene compounds are prone to double bond isomerization during storage and administration. ${ }^{2}$ The $E$-isomers display dramatically reduced inhibition of cancer cell growth and tubulin assembly. ${ }^{3}$ A number of structure-activity relationships (SARs) have been reported for the combretastatins. ${ }^{4}$ These studies revealed that the 3,4,5-trimethoxyphenyl unit as well as the cis orientation of the two aromatic rings is a prerequisite for significant biological activities. Therefore, extensive studies have been conducted to prepare various cis restricted analogues by inserting mainly the cis-olefin in a five-membered heterocyclic ring (e.g.; pyrazoles, thiazoles, triazoles, imidazoles, ....). ${ }^{5}$

Our interest in 1,1-diarylethylene unit synthesis, 6,7 combined with our efforts to discover novel potent tubulin assembly inhibitors, related to CA $-4,{ }^{8}$ led us to identify a promising class of substances with strong anticancer activities, simply by switching the trimethoxyphenyl nucleus from the $C(1)$ to the $C(2)$ position of the ethylene bridge. ${ }^{9}$ In contrast to their natural parent combretastatins $\mathrm{A}$, these synthetic isomers, named isocombretastatins A (isoCA), are easy to synthesize without the need to control the olefin geometry and constitute the simplest isomers of isoCA. The most active compound isoCA-4 appears to elicit its tumor cytotoxicity in a fashion similar to CA-4, via inhibition of tubulin polymerization, which then leads to cell cycle arrest in G2/M. As the replacement of the 1,2-ethylene bridge by the 1,1-ethylene one resulted in retention of biological activity, our finding encouraged us to use this bioisostere ${ }^{10}$ in future structure activity relationship studies. To this end, a set of compounds derived from the general structures $\mathbf{1}$ were considered (Figure 1), and a versatile synthesis that would allow the incorporation of a variety of aryl substituents was therefore needed.
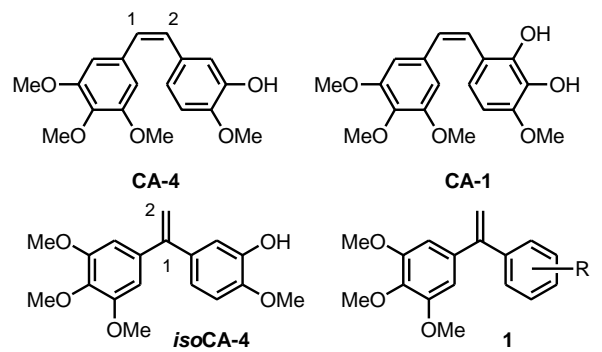

Figure 1. Combretastatins A-1, A-4, synthetic tubulin polymerization inhibitor isoCA-4 and target structure $\mathbf{1}$.

Typically, the synthesis of the most active compound isoCA-4 was performed by the reaction of $3,4,5-$ trimethoxyacetophenone $N$-tosylhydrazone ${ }^{11} \mathbf{2 a}$ with 2tbutyldimethylsilyloxy-4-iodoanisole. Thus, when using $\mathrm{Pd}_{2}(\mathrm{dba})_{3}(10 \mathrm{~mol} \%)$ as a catalyst and Xphos $(20 \mathrm{~mol} \%)$ as a ligand, the coupling reaction gave the desired product isoCA-4 in a $75 \%$ yield. ${ }^{12}$ This synthetic approach proved to be suitable for the synthesis of the others

* Corresponding author. Tel.: +33-1-46.83.58.87; fax: +33-1-46.83.58.28; e-mail: mouad.alami@u-psud.fr

Keywords: Aryl triflates, tosylhydrazones, palladium, Xphos ligand, 1,1-diarylethylenes, isocombretastatin A-4. 
isocombretastatins A-1 to A-5 ${ }^{9 \mathrm{a}}$ since no stoichiometric organometallic reagent was employed and also, in view of the simple transformation of the acetophenones into their corresponding $N$-tosylhydrazones. Although this reaction has been investigated with aryl halides, ${ }^{9 a, 11}$ there is no report employing the use of aryl triflates. Extension of this coupling reaction to include aryl triflates as electrophiles $^{13}$ is especially important since these substrates can be easily synthesized from phenol sources and consequently can be revealed at a late stage in a synthetic sequence. The commercial availability of phenol derivatives will make this approach sufficiently diversity oriented, thus fulfilling the recent demand for the generation of large combinatorial chemical libraries. Herein we report our studies in the synthesis of 1,1diarylethylenes $\mathbf{1}$ from the coupling of polyoxygenated $N$ tosylhydrazone $\mathbf{2}$ with aryl triflates.

Initial studies were performed by coupling 3,4,5trimethoxyacetophenone $N$-tosylhydrazone (2a) and aryl triflate 3a, as model substrates using $\mathrm{Pd}_{2}(\mathrm{dba})_{3}(5 \mathrm{~mol} \%)$, Xphos $(10 \mathrm{~mol} \%)$ and $t \mathrm{BuOLi}(2$ equiv) in dioxane at 90 ${ }^{\circ} \mathrm{C}$. Under these conditions (conventional atmospheric pressure reaction), 1a was formed in a modest $54 \%$ yield (entry 1). Fortunately, a much higher yield was obtained under pressure by running the reaction in a sealed tube ( $84 \%$, entry 2). As summarized in Table 1 , the nature of the base has an influence on the outcome of the reaction. $t \mathrm{BuOLi}$ appeared the base of choice to secure the 1,1diarylethylene 1a formation since performing the same reaction with $t \mathrm{BuOK}, \mathrm{Cs}_{2} \mathrm{CO}_{3}$ or $\mathrm{K}_{3} \mathrm{PO}_{4}$ lead to lower yields (entries 3-6). The screening was continued with respects to palladium source and ligands. We were pleased to find that the catalytic activity of $\mathrm{Pd}(\mathrm{OAc})_{2}$ or $\mathrm{PdCl}_{2}\left(\mathrm{MeCN}_{2}\right.$ proved to be similar to $\mathrm{Pd}_{2}(\mathrm{dba})_{3}$ leading to 1a with excellent yields (89-91\%, entries 9 and 10). $\mathrm{Pd} / \mathrm{C}$ or $\mathrm{Pd}(\mathrm{OH})_{2}$ however, showed moderate catalytic activities (entries 7 and 8) since 1a was formed with lower yields than those obtained with $\mathrm{Pd}(\mathrm{OAc})_{2}$ or $\mathrm{PdCl}_{2}\left(\mathrm{MeCN}_{2}\right.$. Evaluation of ligands revealed that Xphos (L3) and CyJohnPhos (L1) have a similar efficiency and are superior to all other choices (entries 11-13). Finally we examined the effect of the leaving group (LG) of the electrophilic coupling partner. A comparative study revealed that the reactivity of triflate $\mathbf{3 a}$ is superior to that of imidazolylsulfonate $\mathbf{3 b}$ (entry 14) and nonaflate $\mathbf{3 c}$ (entry 15) whereas the coupling failed when using tosylate 3d (entry 16). Considering its high catalytic activity $\mathrm{Pd}(\mathrm{OAc})_{2}$ was our choice for further experimentation. In summary, the best conditions were found to require: $\mathbf{2 a}$ (1 equiv), 3a (1 equiv), $\mathrm{Pd}(\mathrm{OAc})_{2}(5$ mol\%), Xphos (10 mol\%), $t$ BuOLi ( 2 equiv), dioxane in a sealed tube at $90{ }^{\circ} \mathrm{C}$ for $3 \mathrm{~h} .{ }^{14}$ It should be noted that microwave heating is also effective for this reaction. However, if the reaction time is reduced $(\sim 0.5 \mathrm{~h}),{ }^{15} \mathrm{a}$ slightly lower yield $(78 \%)$ was obtained.
Table 1. Initial studies for Pd-Catalyzed Barluenga Coupling of $N$-tosylhydrazone $\mathbf{2 a}$ with $\mathbf{3}^{\text {a }}$

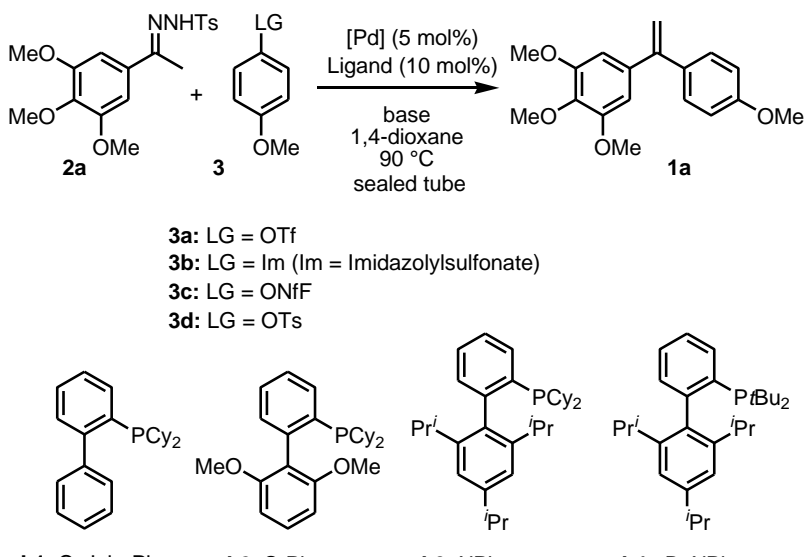

L1: CyJohnPhos L2: S-Phos L3: XPhos L4: tBuXPhos

\begin{tabular}{|c|c|c|c|c|}
\hline Entry & {$[\mathrm{Pd}] /$ Ligand } & LG & Base & $\begin{array}{c}\text { Yield }^{\mathrm{b}} \\
(\%)\end{array}$ \\
\hline 1 & $\mathrm{Pd}_{2}(\mathrm{dba})_{3} / \mathbf{L} \mathbf{3}$ & OTf & $t \mathrm{BuOLi}$ & $54^{\mathrm{c}}$ \\
\hline 2 & $\mathrm{Pd}_{2}(\mathrm{dba})_{3} / \mathbf{L} \mathbf{3}$ & OTf & $t \mathrm{BuOLi}$ & 84 \\
\hline 3 & $\mathrm{Pd}_{2}(\mathrm{dba})_{3} / \mathbf{L} \mathbf{3}$ & OTf & $t \mathrm{BuOK}$ & 34 \\
\hline 4 & $\mathrm{Pd}_{2}(\mathrm{dba})_{3} / \mathbf{L} \mathbf{3}$ & OTf & $\mathrm{Cs}_{2} \mathrm{CO}_{3}$ & 23 \\
\hline 5 & $\mathrm{Pd}_{2}(\mathrm{dba})_{3} / \mathbf{L} \mathbf{3}$ & OTf & $\mathrm{K}_{3} \mathrm{PO}_{4}$ & 50 \\
\hline 6 & $\mathrm{Pd}_{2}(\mathrm{dba})_{3} / \mathbf{L} \mathbf{3}$ & OTf & $\mathrm{Li}_{2} \mathrm{CO}_{3}$ & 0 \\
\hline 7 & $\mathrm{Pd} / \mathrm{C} / \mathbf{L} \mathbf{3}$ & OTf & $t \mathrm{BuOLi}$ & 13 \\
\hline 8 & $\mathrm{Pd}(\mathrm{OH})_{2} / \mathrm{C} / \mathbf{L 3}$ & OTf & $t \mathrm{BuOLi}$ & 30 \\
\hline 9 & $\operatorname{PdCl}_{2}(\mathrm{MeCN})_{2} / \mathbf{L 3}$ & OTf & $t$ BuOLi & 89 \\
\hline 10 & $\operatorname{Pd}(\mathrm{OAc})_{2} / \mathrm{L3}$ & OTf & $t$ BuOLi & 91 \\
\hline 11 & $\mathrm{Pd}(\mathrm{OAc})_{2} / \mathbf{L} \mathbf{1}$ & OTf & $t \mathrm{BuOLi}$ & 82 \\
\hline 12 & $\mathrm{Pd}(\mathrm{OAc})_{2} / \mathbf{L} \mathbf{2}$ & OTf & $t \mathrm{BuOLi}$ & 55 \\
\hline 13 & $\mathrm{Pd}(\mathrm{OAc})_{2} / \mathbf{L 4}$ & OTf & $t \mathrm{BuOLi}$ & 19 \\
\hline 14 & $\mathrm{Pd}(\mathrm{OAc})_{2} / \mathbf{L} \mathbf{3}$ & $\mathrm{OSO}_{2} \mathrm{Im}$ & $t \mathrm{BuOLi}$ & 70 \\
\hline 15 & $\mathrm{Pd}(\mathrm{OAc})_{2} / \mathbf{L} \mathbf{3}$ & ONfF & $t \mathrm{BuOLi}$ & 52 \\
\hline 16 & $\mathrm{Pd}(\mathrm{OAc})_{2} / \mathbf{L} \mathbf{3}$ & OTs & $t \mathrm{BuOLi}$ & 5 \\
\hline
\end{tabular}

a All reactions were heated in a sealed tube in dioxane using $2 \mathbf{a}$ (1 equiv), 3 ( 1 equiv), [Pd] (5 mol\%), Ligand (10 mol\%) and base (2 equiv) at $90{ }^{\circ} \mathrm{C}$ for $3 \mathrm{~h}$.

${ }^{\mathrm{b}}$ Isolated yield of $\mathbf{1 a}$.

${ }^{\mathrm{c}}$ Reaction was performed at $90{ }^{\circ} \mathrm{C}$ at atmospheric pressure.

Table 2. Synthesis of 1,1-diarylethylene $\mathbf{1}^{\mathrm{a}}$

\begin{tabular}{ccccc}
\hline \hline Entry & Hydrazone 2 & ArOTf 3 & Product $\mathbf{1}$ & $\begin{array}{c}\text { Yield }^{\mathrm{b}} \\
(\%)\end{array}$ \\
& $\mathbf{2 a}$ & $\mathbf{3 a}$ & $\mathbf{1 a}$ &
\end{tabular}



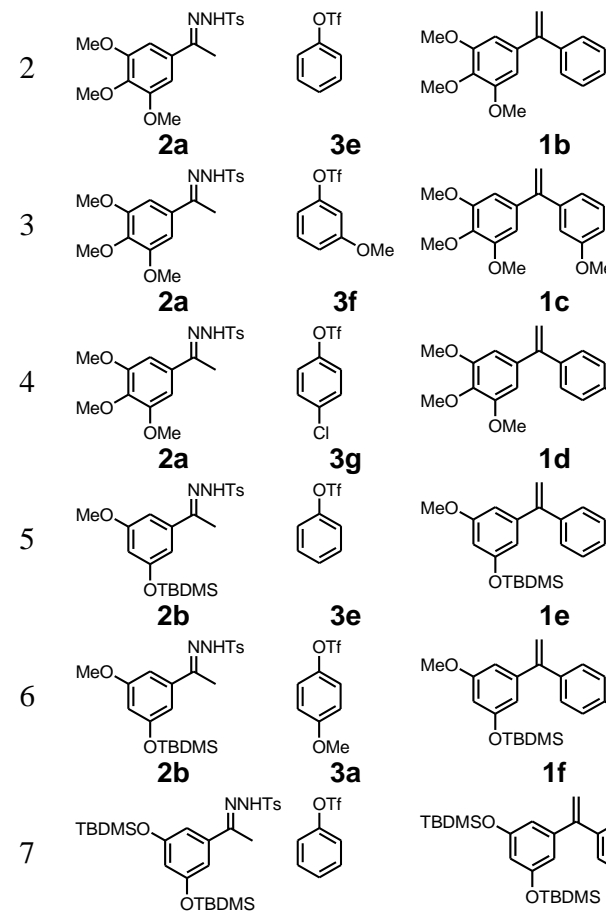<smiles>C=C(c1cccc(OC)c1)c1cc(OC)c(OC)c(OC)c1</smiles><smiles>C=C(c1ccccc1)c1cc(O)cc(OC)c1</smiles><smiles>C=C(c1ccc(OC)cc1)c1ccc(OC)cc1</smiles><smiles>C=C(c1ccccc1)c1cc(O)cc(OC)c1</smiles><smiles>COc1cc(Oc2ccc(OC)cc2O)cc(C(C)=NCc2cccc(O)c2)c1</smiles><smiles>COc1ccc(C(=O)c2cc(O)cc(OC)c2)cc1</smiles>

10<smiles>CN=C(C)c1cc([N+](=O)[O-])c(O[N+](=O)[O-])cc1[N+](=O)[O-]</smiles>

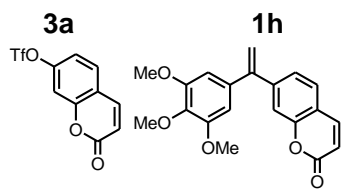
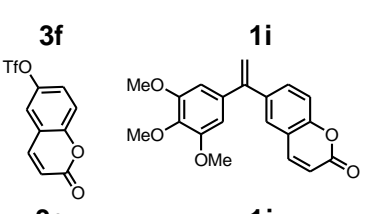

11<smiles>CCN=C(C)c1cc(OC)c(OC)c(OC)c1</smiles><smiles>[Ge]c1ccncc1</smiles><smiles>C=IC(=Cc1cc(O)c(O)c([N+](=O)[O-])c1)c1ccc[nH]1</smiles>

selectively 1d in a $69 \%$ yield (entry 4). Among these substrates, the coupling reaction worked efficiently even in the case of alkaline sensitive tosylhydrazones $\mathbf{2 b}$ and $\mathbf{2 c}$ bearing silyloxy groups in good to excellent yields (entries 5-8). Heteroaromatic triflates 3f-e also were coupled successfully with hydrazone $\mathbf{2 a}$ and provided the desired coupling products $\mathbf{1 i}-\mathbf{k}$ in a satisfactory yields (entries 9-11), despite the fact that the reaction conditions with these heterocyclic substrates had never been optimized.

In conclusion, we have described an efficient and general method for cross coupling of different aryl triflates with polyoxygenated hydrazones catalyzed by the combination of $\mathrm{Pd}(\mathrm{OAc})_{2}$ or $\mathrm{PdCl}_{2}(\mathrm{MeCN})_{2}$ and Xphos ligand in the presence of $t \mathrm{BuOLi}$ as base in a sealed tube. In our opinion, this approach seems to be a suitable method for the synthesis of others isocombretastatin A analogues. The design of antitumor agents based on the 1,1diaryethylene scaffold in future structure-activity relationship studies is currently underway; the results of synthetic and biological studies will be reported in due course.

Acknowledgment. We thank the CNRS for support of this research and the ICSN for a doctoral fellowship to B.T.

1 (a) Pettit, G. R.; Singh, S. B.; Niven, M. L.; Hamel, E.; Schmidt, J. M. J. Nat. Prod. 1987, 50, 119-131. (b) Pettit, G. R.; Singh, S. B.; Boyd, M. R.; Hamel, E.; Pettit, R. K.; Schmidt, J. M.; Hogan, F. J. Med. Chem. 1995, 38, 1666-1672. (d) Pettit, G. R; Singh, S. B.; Hamel, E.; Lin, C. M.; Alberts, D. S.; Garcia-Kendall, D. Experientia 1989, 45, 209-211.

2 Pettit, G. R.; Toki, B.; Herald, D. L.; Boyd, M. R.; Hamel, E.; Pettit, R. K. Chapuis, G. C. J. Med. Chem. 1999, 42, 1459-1465.

3. (a) Cushman, M.; Nagarathnam, D.; Gopal, D.; Chakraborti, A. K.; Lin, C. M.; Hamel, E. J. Med. Chem. 1991, 34, 2579-2588. (b) Cushman, M.; Nagarathnam, D.; Gopal, D.; He, H.-M.; Lin, C. M.; Hamel, E. J. Med. Chem. 1992, 35, 2293-2306.

4 For a review, see: (a) Tron, G. C.; Pirali, T.; Sorba, G.; Pagliai, F.; Dusacca, S.; Genazzani, A. A. J. Med. Chem. 2006, 49, 3033-3044. For some recent works, see: (b) Ty, N.; Kaffy, J.; Arrault, A.; Thoret, S.; Pontikis, R.; Dubois, J.; Morin-Allory, L.; Florent, J.-C. Bioorg. Med. Chem. Lett. 2009, 19, 1318-1322. (c) Ty, N.; Dupeyre, G.; Chabot, G. G.; Seguin, J.; Tillequin, F.; Scherman, D.; Michel, S.; Cachet, X. Bioorg. Med. Chem. Lett. 2008, 16, 7494-7503. (d) Lai, M.-J.; Kuo, C.-Y.; Yeh, T.-K.; Hsieh, H.-P.; Chen, L.-T.; Pan, W.-Y.; Hsu, K.-Y.; Chang, J.-Y.; Liou, J.-P. ChemMedChem. 2009, 4, 588-593.

${ }^{a}$ All reactions were heated in a sealed tube in dioxane using $2 \mathbf{a}$ (1 equiv), 3 (1 equiv), $\mathrm{Pd}(\mathrm{OAc})_{2}(5 \mathrm{~mol} \%)$, XPhos $(10 \mathrm{~mol} \%)$ and $t \mathrm{BuOLi}$ (2 equiv) at $90^{\circ} \mathrm{C}$ for $3 \mathrm{~h}$.

${ }^{b}$ Isolated yield of $\mathbf{1}$.

${ }^{c}$ Not optimized.

After these optimization studies, we applied this catalytic system for the coupling of various aryl triflates and polyoxygenated tosylhydrazones 2 to assess the scope of the developed reaction conditions (Table 2). First, 3,4,5trimethoxyacetophenone $N$-tosylhydrazone $\mathbf{2 a}$ was reacted with various aryl triflates $\mathbf{3}$ to afford the corresponding 1,1-diarylethylenes 1a-c (entries 1-3). Running the reaction from aryl triflate $\mathbf{3 g}$ bearing a para sp2-carbon-chlorine bond, the coupling reaction gave
5 (a) Nam. N. H. Curr. Med. Chem. 2003, 10, 1697-1722. (b) Odlo, K.; Hentzen, J.; Fournier dit Chabert, J.; Ducki, S.; Gani, O. A. B. S. M.; Sylte, I.; Skrede, M.; Flørenes, V. A.; Hansen, T. V. Bioorg. Med. Chem. 2008, 16, 4829-4838. (c) Congiu, C.; Cocco, M. T.; Onnis, V. Bioorg. Med. Chem. Lett. 2008, 18, 989-993. (d) Xue, N.; Yang, X.; Wu, R.; Chen, J.; He, Q.; Yang, B.; Lu, X.; Hu Y. Bioorg. Med. Chem. 2008, 16, 2550-2557. (e) Zhang, Q.; Peng, Y.; Wang, X. I.; Keenan, S. M.; Arora, S.; Welsh, W. J. J. Med. Chem. 2007, 50, 749-754.

6 (a) Hamze, A.; Veau, D.; Provot, O.; Brion, J.-D.; Alami, M. J. Org. Chem. 2009, 74, 1337-1340. (b) Liron, F.; Gervais, M.; Peyrat, J.F.; Alami, M.; Brion, J.-D. Tetrahedron Lett. 2003, 44, 2789-2794.

7 For some recent preparations of 1,1-diarylethylenes see: (a) Bhilare, S. V.; Darvatkar, N. B.; Deorukhkar, A. R.; Raut, D. G.; Trivedi, G. K.; Salunkhe, M. M. Tetrahedron Lett. 2009, 50, 893896. (b) Yadav, J. S.; Reddy, B. V. S.; Sengupta, S.; Biswas, S. K. 
Synthesis 2009, 1301-1304. (c) Sabarre, A.; Love, J. Org. Lett. 2008, 10, 3941-3944. (d) Yoshida, K.; Shishikura, Y.; Takahashi, H.; Imamoto, T. Org. Lett. 2008, 10, 2777-2780. (e) Yuan, D.-Y.; Tu, Y.-Q.; Fan, C.-A. J. Org. Chem. 2008, 73, 7797-7799. (f) Li, J.-H.; Li, J.-L.; Xie, Y.-X. Synthesis 2007, 984-988. (g) Buettner, M. W.; Naetscher, J. B.; Burschka, C.; Tacke, R. Organometallics 2007, 26, 4835-4838. Hansen, A. L.; Ebran, J. P.; Gogsig, T. M.; Skrydstrup, T. Chem. Commun. 2006, 4137-4139. (h) Caldwell, S. T.; Quin, C.; Edge, R.; Hartley, R. C. Org. Lett. 2007, 9, 34993502 .

8 (a) Provot, O.; Giraud, A.; Peyrat, J.-F.; Alami, M.; Brion, J.-D. Tetrahedron Lett. 2005, 46, 8547-8550. (b) Mousset, C.; Giraud, A.; Provot, O.; Hamze, A.; Bignon, J.; Liu, J. M.; Thoret, S.; Dubois, J.; Brion, J.-D.; Alami, M. Bioorg. Med. Chem. Lett. 2008, 18, 3266-3271. (c) Mousset, C.; Provot, O.; Hamze, A.; Bignon, J.; Brion, J.-D.; Alami, M. Tetrahedron 2008, 64, 4287-4294. (d) Giraud, A.. Provot, O.; Hamze, A.; Brion, J.-D.; Alami, M. Tetrahedron Lett. 2008, 49, 1107-1110.

9 (a) Messaoudi, S.; Tréguier, B.; Hamze, A.; Provot, O.; Peyrat, J.F.; Rodrigo De Losada, J. R.; Liu, J.-M.; Bignon, J.; WdzieczakBakala, J.; Thoret, S.; Dubois, J.; Brion, J.-D.; Alami, M. J. Med. Chem. 2009, 52, 4538-4542. (b) Alami, M.; Brion, J.-D.; Provot, O.; Peyrat, J.-F.; Messaoudi, S.; Hamze, A.; Giraud, A.; Bignon, J.; Bakala, J.; Liu, J.-M. WO 122620 A1, 2008.

10 Patani, G. A.; LaVoie, E. J. Chem. Rev. 1996, 96, 3147-3176.

11 (a) Barluenga, J.; Moriel, P.; Valdés, C.; Aznar, F. Angew. Chem. Int. Ed. 2007, 46, 5587-5590. (b) Barluenga, J.; Tomas-Gamasa, M.; Moriel, P.; Aznar, F.; Valdés, C. Chem. Eur. J. 2008, 14, 47924795.

12 Only $50 \%$ of the desired product was obtained when running the coupling reaction with $\mathrm{Pd}_{2}(\mathrm{dba})_{3}(1 \mathrm{~mol} \%)$ and Xphos $(2 \mathrm{~mol} \%)$.

13 For excellent reviews, see: (a) Ritter, K. Synthesis 1993, 735-762. (b) Baraznenok, I. L.; Nenajdenko, V. G.; Balenkova, E. S. Tetrahedron 2000, 56, 3077-3119.

14 General procedure for the synthesis of 1 . To a dioxane $(6 \mathrm{~mL})$ solution of $N$-tosylhydrazone $2(0.5 \mathrm{mmol}), t \mathrm{BuOLi}(1 \mathrm{mmol})$, $\mathrm{Pd}(\mathrm{OAc})_{2}(0.025 \mathrm{mmol})$ and $\mathrm{X}-\mathrm{Phos}(0.05 \mathrm{mmol})$ was added the aryl triflate $3(0.5 \mathrm{mmol})$ in dioxane $(2 \mathrm{~mL})$. The reaction vessel was sealed, and then heated at $90{ }^{\circ} \mathrm{C}$ for $3 \mathrm{~h}$. The resulting suspension was cooled to room temperature and filtered through a pad of Celite eluting with AcOEt, and the inorganic salts were removed. The filtrate was concentrated and purification of the residue by silica gel column chromatography gave the desired product.

Diarylethylene 1a: Yield: $91 \%$. $\mathrm{R}_{f}$ (cyclohexane/EtOAc : 6/4) $=$ 0.60 . IR $\left(\mathrm{cm}^{-1}\right): 1579,1507,1454,1411,1346,1299,1233,1174$, $1122,1030,1004 .{ }^{1} \mathrm{H}$ RMN: $\left(\delta \mathrm{ppm}, \mathrm{CD}_{3} \mathrm{COCD}_{3} 300 \mathrm{MHz}\right): 3.75$ $\left(\mathrm{s}, 3 \mathrm{H}, \mathrm{OCH}_{3}\right), 3.78\left(\mathrm{~s}, 6 \mathrm{H}, \mathrm{OCH}_{3}\right), 3.82\left(\mathrm{~s}, 3 \mathrm{H}, \mathrm{OCH}_{3}\right), 5.34(\mathrm{~m}$, $\left.2 \mathrm{H}, \mathrm{CH}_{2}\right), 6.60(\mathrm{~s}, 2 \mathrm{H}), 6.92(\mathrm{~d}, 2 \mathrm{H}, J=8.7 \mathrm{~Hz}), 7.29(\mathrm{~d}, 2 \mathrm{H}, J=8.7$ $\mathrm{Hz}) .{ }^{13} \mathrm{C}$ NMR $\left(\delta \mathrm{ppm}, 75 \mathrm{MHz}, \mathrm{CD}_{3} \mathrm{COCD}_{3}\right): 55.5,56.4$ (2), 60.5, 106.8 (2), 112.7, 114.4 (2), 130.1 (2), 134.4, 138.2 (2), 150.6, 154.1 (2), 160.5 .

Diarylethylene 1d: Yield: 69\%. $\mathrm{R}_{f}$ (cyclohexane/EtOAc : 9/1) $=$ 0.58. IR $\left(\mathrm{cm}^{-1}\right): 1579,1504,1462,1410,1344,1235,1125,1007 .{ }^{1} \mathrm{H}$ RMN: $\left(\delta \mathrm{ppm}, \mathrm{CDCl}_{3}, 300 \mathrm{MHz}\right): 3.73\left(\mathrm{~s}, 6 \mathrm{H}, \mathrm{OCH}_{3}\right), 3.80(\mathrm{~s}, 3 \mathrm{H}$, $\left.\mathrm{OCH}_{3}\right), 5.34\left(\mathrm{~d}, 2 \mathrm{H}, \mathrm{J}=1.0 \mathrm{~Hz}, \mathrm{CH}_{2}\right), 6.44(\mathrm{~s}, 2 \mathrm{H}, \mathrm{CH}), 7.22(\mathrm{~s}, 4 \mathrm{H}$, $\mathrm{CH}) .{ }^{13} \mathrm{C}$ NMR $\left(\delta \mathrm{ppm}, 75 \mathrm{MHz}, \mathrm{CDCl}_{3}\right): 56.1$ (2), 60.9, 105.5 (2), $114.3,128.4$ (2), 129.6 (2), 133.7, 136.8, 137.8, 139.7, 149.0, 153.0 (2).

Diarylethylene 1i: Yield: $75 \% . . R_{f}($ cyclohexane/EtOAc : $7 / 3)=$ 0.28 . Mp: $143-145{ }^{\circ} \mathrm{C}$. IR $\left(\mathrm{cm}^{-1}\right): 1719,1574,1508,1453,1411$, 1350, 1221, 1177, 1124, 996. ${ }^{1} \mathrm{H}$ RMN: $\left(\delta \mathrm{ppm}, \mathrm{CDCl}_{3}, 300 \mathrm{MHz}\right)$ : $3.82(\mathrm{~s}, 6 \mathrm{H}), 3.89(\mathrm{~s}, 3 \mathrm{H}), 5.54(\mathrm{~s}, 1 \mathrm{H}), 5.56(\mathrm{~s}, 1 \mathrm{H}), 6.42(\mathrm{~d}, 1 \mathrm{H}$, $\mathrm{J}=9.5 \mathrm{~Hz}), 6.51(\mathrm{~s}, 2 \mathrm{H}), 7.27(\mathrm{dd}, 1 \mathrm{H}, \mathrm{J}=1.6 \mathrm{~Hz}, \mathrm{~J}=8.0 \mathrm{~Hz}), 7.35(\mathrm{~d}$, $1 \mathrm{H}, \mathrm{J}=1.5 \mathrm{~Hz}), 7.44(\mathrm{~d}, 1 \mathrm{H}, \mathrm{J}=8.0 \mathrm{~Hz}), 7.71(\mathrm{~d}, 1 \mathrm{H}, \mathrm{J}=9.5 \mathrm{~Hz}) \cdot{ }^{13} \mathrm{C}$ NMR ( $\delta$ ppm, $75 \mathrm{MHz}, \mathrm{CDCl}_{3}$ ): 56.0 (2), 60.8, 105.6 (2), 116.1, $116.2,116.4,118.2,124.3,127.4,136.0,138.1,142.9,145.1,148.6$, $153.0(2), 153.9,160.6$.

15 The reaction was conducted according to the general method described above. The reaction vessel was sealed, then placed in the Emrys Optimizer and exposed to microwave irradiation according to the following specifications: temperature: $120{ }^{\circ} \mathrm{C}$; time: $30 \mathrm{~min}$; fixed hold time: on; sample absorption: high; pre-stirring: $60 \mathrm{~s}$. 